\title{
A thermoalkaliphilic lipase of Geobacillus sp. T1
}

\begin{abstract}
A thermoalkaliphilic T1 lipase gene of Geobacillus sp. strain T1 was overexpressed in pGEX vector in the prokaryotic system. Removal of the signal peptide improved protein solubility and promoted the binding of GST moiety to the glutathione-Sepharose column. High-yield purification of T1 lipase was achieved through two-step affinity chromatography with a final specific activity and yield of $958.2 \mathrm{U} / \mathrm{mg}$ and $51.5 \%$, respectively. The molecular mass of T1 lipase was determined to be approximately $43 \mathrm{kDa}$ by gel filtration chromatography. $\mathrm{T} 1$ lipase had an optimum temperature and $\mathrm{pH}$ of $70^{\circ} \mathrm{C}$ and $\mathrm{pH} 9$, respectively. It was stable up to $65^{\circ} \mathrm{C}$ with a half-life of $5 \mathrm{~h} 15 \mathrm{~min}$ at $\mathrm{pH} 9$. It was stable in the presence of $1 \mathrm{mM}$ metal ions $\mathrm{Na}+, \mathrm{Ca} 2+, \mathrm{Mn} 2+, \mathrm{K}+$ and $\mathrm{Mg} 2+$, but inhibited by $\mathrm{Cu} 2+, \mathrm{Fe} 3+$ and $\mathrm{Zn} 2+$. Tween 80 significantly enhanced T1 lipase activity. T1 lipase was active towards medium to long chain triacylglycerols $(\mathrm{C} 10-\mathrm{C} 14)$ and various natural oils with a marked preference for trilaurin (C12) (triacylglycerol) and sunflower oil (natural oil). Serine and aspartate residues were involved in catalysis, as its activity was strongly inhibited by $5 \mathrm{mM}$ PMSF and $1 \mathrm{mM}$ Pepstatin. The $\mathrm{T} \mathrm{m}$ for $\mathrm{T} 1$ lipase was around $72.2^{\circ} \mathrm{C}$, as revealed by denatured protein analysis of CD spectra.
\end{abstract}

Keyword: Geobacillus sp., Thermoalkaliphilic, Overexpression, Purification, Thermostable lipase 